\title{
The Impact of Foreign Direct Investment on Poverty Reduction in Turkey: A Time Series Analysis
}

\author{
Prof. Dr. Neşe Algan (Çukurova University, Turkey) \\ Prof. Dr. Harun Bal (Çukurova University, Turkey) \\ Ph.D. Candidate Murat Bayraktar (Çukurova University, Turkey)
}

\begin{abstract}
Foreign direct investment can be outlined as the net inflows of investment to take possession of permanent management. Foreign direct investments can support poverty alleviation especially for developing countries which needs capital. Global foreign direct investment sums $\$ 1.5$ trillion in 2019 decreased to a calculated $\$ 859$ billion in 2020 as the UNCTAD report indicates. Foreign direct investment flows are expected to remain weak with uncertainty due to Covid-19. For almost 25 years, extreme poverty, was steadily declining, on the contrary, expected to rise in 2020 between 88 million and 115 million added as the disruption of the Covid-19 on the global supply chain due to lockdowns.

Time series analysis of foreign direct investments and poverty reduction relationship for Turkey between the 1996-2019 period confirms that foreign direct investment net infows reduce poverty: \%1 increase of FDI inflow to Turkey increases \% 0.011 of household final consumption which used as proxy for poverty. Turkish policymakers should develop an appropriate economic environment to appeal as much as foreign direct investment to Turkey.
\end{abstract}

\section{Introduction}

Foreign direct investment is an investment made by a firm or individual in one country for commercial purposes in another country. Foreign direct investments often involve more than just a capital investment. The most important feature of foreign direct investment is that it effectively controls or at least significantly influences the decision-making process of a foreign enterprise.

FDI inflows are in a constant upward trend, except for the years in which economic crises and unstable cyclical fluctuations were experienced. According to the 2015 World Investment Report of the United Nations Conference on Trade and Development, developing countries have managed to receive 55\% of the world's FDI. Although it is seen as an important indicator of development, it is difficult to measure the economic effects of FDI exactly. The effects of FDI on the country's economy depend on different factors. It varies according to the sector in which the investment is made, the type of investment, the attitude of foreign companies towards the host country, and the conditions in the country (Nur and Dilber, 2017: 16).

As seen from Table 1, Investment Trends Monitor (UNCTAD, 2021) report says global foreign direct investment decreased around $42 \%$ in the year 2020 from $\$ 1.5$ trillion in 2019 to an estimated $\$ 859$ billion, also the same report expects global FDI flows to remain fragile due to uncertainty of the COVID-19 pandemic. In 2019, net FDI inflows (\% of GDP) for Turkey was $1.2 \%$.

\begin{tabular}{|l|l|l|l|}
\hline Total Shares & $\mathbf{2 0 1 9}$ & $\mathbf{2 0 2 0}$ & $\mathbf{2 0 2 1} *$ \\
\hline Global FDI & \$1.5 trillion & \$859 billion (- \%42) & \$774 to \$817 billion \\
\hline Developed economies & \$730 billion & \$229 billion (- \%69) & \\
\hline North America & \$166 billion & \$309 billion (-\%46) & \\
\hline Developing countries & \$702 billion & \$616 billion (-\%12) & \\
\hline Turkey & \$9,266 billion & $\$ 7.7$ billion (-\%16.5) & \\
\hline
\end{tabular}

Table 1. Global FDI (billion US \$).Source: UNCTAD 2021, * estimate.

\section{Literature review on foreign direct investment and poverty relationship}

According to the World Bank 2005 report, global FDI flows raised from US \$55 billion in 1958 to US \$573 billion in 2003 (Nourbakhshian et al, 2012). Over the past 20 years, FDI flows increased in many countries thus showing an indication of the globalization to the global economy (Busse and Groiozard, 2005).

For countries with insufficient capital accumulation, it becomes necessary to resort to external financing resources, and foreign direct investments play a prominent role in closing this gap. It is accepted that foreign direct investments have various benefits for the host countries. Multinational companies that make FDI transfer the technology they use to the country they invest in, take production knowledge, management and organization experience, and marketing information with them, increase competition with efficiency in the national and international market of the host country, facilitate information trade, and positively affect the foreign trade balance predicted to affect (Şahbaz, et. al, 2016: 1107). 


\begin{tabular}{|c|c|c|c|}
\hline Author & $\begin{array}{l}\text { Country/Countries } \\
\text { of study, Period }\end{array}$ & Methodology & Findings \\
\hline $\begin{array}{l}\text { Ato-Mensah, and } \\
\text { Long (2021) }\end{array}$ & Ghana & Research article & $\begin{array}{l}\text { FDI can promote economic } \\
\text { development, employment } \\
\text { and reduce poverty in Ghana }\end{array}$ \\
\hline Hanim (2021) & $\begin{array}{l}\text { Indonesia } \\
33 \text { provinces } \\
2012-2016 \\
\end{array}$ & $\begin{array}{l}\text { multiple regression and } \\
\text { moderation regression } \\
\text { models }\end{array}$ & $\begin{array}{l}\text { FDI had a significant positive } \\
\text { effect on economic growth }\end{array}$ \\
\hline $\begin{array}{l}\text { Sikandar et al. } \\
(2021)\end{array}$ & $\begin{array}{l}14 \text { developing economies } \\
\text { of Latin America, Asia, } \\
\text { and Eastern Europe }\end{array}$ & $\begin{array}{l}\text { panel unit root test and } \\
\text { pool mean group } \\
\text { estimation }\end{array}$ & $\begin{array}{l}\text { poverty reduction could be } \\
\text { positively affected }\end{array}$ \\
\hline $\begin{array}{l}\text { Nguea, Noumba } \\
\text { and Noula }(2020)\end{array}$ & Cameroon & $\begin{array}{l}\text { ARDL-Bounds Testing } \\
\text { Approach }\end{array}$ & $\begin{array}{l}\text { A short-run positive impact of } \\
\text { FDI on poverty }\end{array}$ \\
\hline $\begin{array}{l}\text { Ahmad et. al } \\
(2019)\end{array}$ & $\begin{array}{l}\text { ASEAN and SAARC } \\
\text { economies } \\
\text { 1990-2014 }\end{array}$ & Panel regression model & $\begin{array}{l}\text { The positive and strongly } \\
\text { significant relationship } \\
\text { between FDI net inflows and } \\
\text { poverty reduction }\end{array}$ \\
\hline Durowah (2018) & $\begin{array}{l}91 \text { developing } \\
\text { countries } \\
2000-2014\end{array}$ & Panel data analysis & FDI reduced poverty \\
\hline Trinh (2017) & $\begin{array}{l}63 \text { provinces of } \\
\text { Vietnam } \\
2002-2012 \\
\end{array}$ & $\begin{array}{l}\text { Panel data } \\
\text { analysis }\end{array}$ & FDI reduced poverty \\
\hline Hmani (2017) & $\begin{array}{l}\text { MENA region } \\
1990-2014\end{array}$ & $\begin{array}{l}\text { Simultaneous } \\
\text { Equations Model }\end{array}$ & FDI reduced poverty \\
\hline Arabyat (2017) & $\begin{array}{l}\text { Developing countries } \\
1980-2012\end{array}$ & $\begin{array}{l}\text { Unbalanced panel data } \\
\text { analysis }\end{array}$ & $\begin{array}{l}\text { A negligible positive impact } \\
\text { of FDI on poverty reduction }\end{array}$ \\
\hline $\begin{array}{l}\text { Awunyo and } \\
\text { Sackey (2018) }\end{array}$ & $\begin{array}{l}\text { Ghana } \\
1975 \text { to } 2017\end{array}$ & $\begin{array}{l}\text { Descriptive statistic, unit } \\
\text { root test, Granger causality } \\
\text { test and error correction } \\
\text { model (ECM). }\end{array}$ & $\begin{array}{l}\text { A unit change in FDI flow } \\
\text { into the agricultural sector will } \\
\text { cause a } 2,6 \% \text { unit change in } \\
\text { economic growth }\end{array}$ \\
\hline $\begin{array}{l}\text { Fauzel, Seetanah } \\
\text { and Sannassee } \\
(2016)\end{array}$ & $\begin{array}{l}\text { Mauritius } \\
1980-2013\end{array}$ & $\begin{array}{l}\text { Dynamic vector } \\
\text { autoregressive model }\end{array}$ & $\begin{array}{l}\text { Uni-directional causality } \\
\text { between FDI and poverty } \\
\text { reduction. }\end{array}$ \\
\hline Uttama (2015) & $\begin{array}{l}\text { Southeast Asia } \\
1995-2011\end{array}$ & $\begin{array}{l}\text { Panel data } \\
\text { analysis }\end{array}$ & FDI reduced poverty \\
\hline Soumare (2015) & $\begin{array}{l}\text { Northern Africa } \\
1990-2011\end{array}$ & $\begin{array}{l}\text { Dynamic panel data } \\
\text { regression }\end{array}$ & FDI reduced poverty \\
\hline $\begin{array}{l}\text { Fowowe and } \\
\text { Shuaibu (2014) }\end{array}$ & $\begin{array}{l}\text { selected African } \\
\text { economies }\end{array}$ & $\begin{array}{l}\text { System generalized } \\
\text { method of moments }\end{array}$ & FDI reduced poverty \\
\hline $\begin{array}{l}\text { Reiter and } \\
\text { Steensma, (2010) }\end{array}$ & $\begin{array}{l}49 \text { developing countries } \\
1980-2005\end{array}$ & Unbalanced panel data & FDI reduced poverty \\
\hline $\begin{array}{l}\text { Gohou and } \\
\text { Soumare (2012) }\end{array}$ & $\begin{array}{l}52 \text { African countries } \\
1990-2007\end{array}$ & $\begin{array}{l}\text { Panel data } \\
\text { analysis }\end{array}$ & FDI reduced poverty \\
\hline $\begin{array}{l}\text { Zaman et al. } \\
(2012)\end{array}$ & $\begin{array}{l}\text { Pakistan } \\
1985-2011 \\
\end{array}$ & Ordinary Least Squares & FDI reduced poverty \\
\hline $\begin{array}{l}\text { Apergis et al } \\
(2007)\end{array}$ & $\begin{array}{l}27 \text { transitional European } \\
\text { economies } \\
1991-2004\end{array}$ & Panel dataset & FDI reduced poverty \\
\hline $\begin{array}{l}\text { Hansen and Rand } \\
(2006)\end{array}$ & $\begin{array}{l}31 \text { developing countries } \\
1970-2000\end{array}$ & $\begin{array}{l}\text { Bivariate vector } \\
\text { autoregressive model }\end{array}$ & $\begin{array}{l}\text { A strong causal link between } \\
\text { FDI and GDP, even in the } \\
\text { long run }\end{array}$ \\
\hline $\begin{array}{l}\text { Jalilian and Weiss } \\
(2002)\end{array}$ & $\begin{array}{l}\text { ASEAN countries } \\
1991-1997\end{array}$ & $\begin{array}{l}\text { Panel data } \\
\text { analysis }\end{array}$ & FDI reduced poverty \\
\hline
\end{tabular}

Table 2. Literature review. Source: Magombeyi et. al, 2017. Tsaurai, 2018. 
The general opinion about the relationship between FDI and its affect on economic development is mixed, but the majority of research remarks that FDI increases economic growth. The spillover effects can be seen in the enhancing exportability of local firms and the use of modern technology can promote competition. Another linkage of direct impact is in job opportunities if the percentage of job opportunities is remarkably larger than FDI-related unemployment (Ahmad et al, 2019: 3-4).

FDI brings capital and technology to target firms, industries, and locations, affecting demand for labor force composition, employment, average productivity, wage levels, and wage inequality. For developing economies, the literature also finds an overwhelmingly positive effect on total employment and productivity, while the effects on these outcomes for advanced economies are mixed (Hale and $\mathrm{Xu}, 2016$ ).

UNCTAD (2012) report remarks that FDI has the magnitude to reduce poverty in emerging and developing countries due to its ability to guide positive economic development and growth. The majority of theoretical literature reinforces that FDI has an indirect positive impact on poverty through its capacity to intensify economic growth.

Sometimes FDI can cause both positive and negative spillover effects to the host country. The opposition views are listed such as FDI may crowding out effect on domestic investment, external vulnerability and dependence, destructive competition of foreign connections to domestic firms (Nourbakhshian et al, 2012).

In Table 2, a list of the literature review is given as positive relationship found by authors between FDI and poverty.

In Table 3, a list of the literature review is given as negative relationship found by authors between FDI and poverty.

\begin{tabular}{|l|l|l|l|}
\hline Le et al. (2021) & $\begin{array}{l}\text { Vietnam } \\
\mathbf{2 0 1 2 - 2 0 1 8}\end{array}$ & $\begin{array}{l}\text { Generalized Method of } \\
\text { Moment (GMM) }\end{array}$ & $\begin{array}{l}\text { FDI increase } \\
\text { income inequality }\end{array}$ \\
\hline $\begin{array}{l}\text { Lazreg and } \\
\text { Zouari (2018) }\end{array}$ & $\begin{array}{l}\text { North Africa } \\
\text { Fully modified } \\
\text { ordinary least } \\
\text { squares (FMOLS) }\end{array}$ & $\begin{array}{l}\text { FDI increased } \\
\text { poverty when GINI } \\
\text { index was used }\end{array}$ \\
\hline $\begin{array}{l}\text { Basnet and Pradhan } \\
(2014)\end{array}$ & $\begin{array}{l}\text { five SAARC countries } \\
1990 \text { to 2010 }\end{array}$ & Time-series data & $\begin{array}{l}\text { FDI on economic } \\
\text { growth is not } \\
\text { significant }\end{array}$ \\
\hline Herzer (2012) & 44 developing countries & $\begin{array}{l}\text { heterogeneous panel co- } \\
\text { integration techniques }\end{array}$ & $\begin{array}{l}\text { A negative effect on } \\
\text { growth in } \\
\text { developing } \\
\text { countries }\end{array}$ \\
\hline $\begin{array}{l}\text { Huang et al. } \\
(2010)\end{array}$ & $\begin{array}{l}12 \text { countries from East } \\
\text { and Latin America 1970- } \\
2005\end{array}$ & Unbalanced panel data & $\begin{array}{l}\text { Inward FDI to have } \\
\text { a negative impact } \\
\text { on poverty } \\
\text { reduction }\end{array}$ \\
\hline $\begin{array}{l}\text { Ali and Nishat } \\
(2010)\end{array}$ & Pakistan & $\begin{array}{l}\text { Ordinary least squares } \\
\text { ARDL }\end{array}$ & $\begin{array}{l}\text { A negative } \\
\text { relationship } \\
\text { between FDI and } \\
\text { poverty reduction }\end{array}$ \\
\hline
\end{tabular}

Table 3. Literature review. Source: Magombeyi et. al, 2017. Tsaurai, 2018.

In Table 4, a list of the literature review is given as insignificant relationship found by authors between FDI and poverty.

\begin{tabular}{|l|l|l|l|}
\hline $\begin{array}{l}\text { Ogunniyi and Igberi, } \\
(2014)\end{array}$ & Nigeria & $\begin{array}{l}\text { Ordinary least squares } \\
\text { OLS }\end{array}$ & Insignificant impact \\
\hline Herzer et al. (2008) & 28 developing countries & co-integration techniques & $\begin{array}{l}\text { No evidence for the } \\
\text { long- and short-run } \\
\text { impact of FDI on } \\
\text { economic growth }\end{array}$ \\
\hline $\begin{array}{l}\text { Tsai and Huang } \\
(2007)\end{array}$ & $\begin{array}{l}\text { Taiwan } \\
1964-2003\end{array}$ & Time series data & $\begin{array}{l}\text { FDI have an } \\
\text { insignificant impact } \\
\text { on the average } \\
\text { income of the poor. }\end{array}$ \\
\hline
\end{tabular}

Table 4. Literature review. Source: Magombeyi et. al, 2017. Tsaurai, 2018. 


\section{FDI inflows and poverty in Turkey}

Between 1980 and 2002, total FDI into Turkey was around USD 15 billion, while the country has since attracted around USD 225 billion of FDI with finance (\%33) and manufacturing (\%24) sectors has attracted the highest number of investments in Turkey during the 2003-2020 period. The majority of FDI inflows to Turkey have originated from Europe (Netherlands, \% 15,9), North America (\%7,8), and the Gulf countries (\%7) during the past 17 years. As of end-2020, the number of companies with foreign capital in Turkey reached almost 74,000 up from 5,600 in the year 2002 (Investment Office, 2021).

According to World Bank's Doing Business Report “Ease of Doing Business” Turkeys' 2017 rank is 60, 2018 rank was 43 and 2019 rank is 33 of 1-190. A high ease of doing business ranking indicates that regulatory environment is more helpful to the starting and running of a local firm. New Zealand has rank 1 and Singapore has rank 2 for the year 2019 (WB, 2021d).

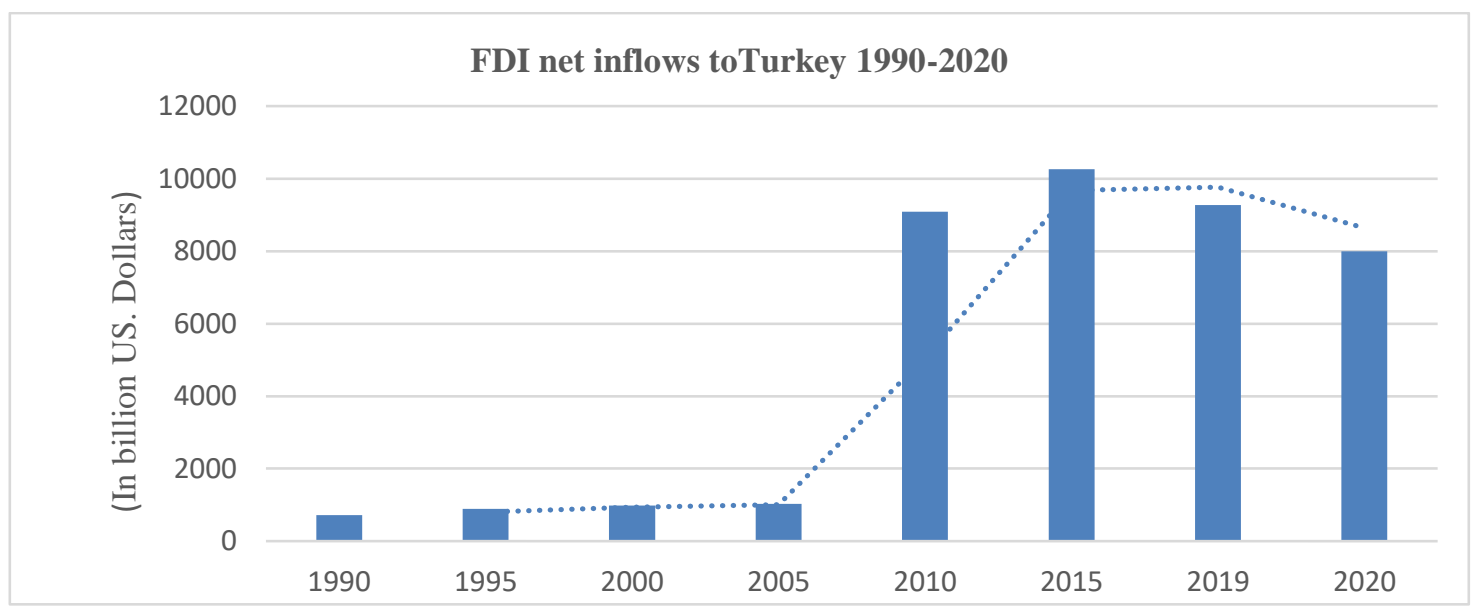

Figure 1. FDI net Inflows to Turkey 1990-2020 (billion US \$). Source: WB (2021a).

Turkish companies' FDI outflow has increased by almost 10 times over the past 15 years. Turkish businesses made a total of 85 greenfield investments abroad which totaled around $\$ 2.8$ billion in the year 2016, a report from the Foreign Investments of Turkey Index, which was prepared by DEIK and Bain \& Company (Hürriyet, 2017). $10 \%$ of all greenfield investments and acquisitions made by Turkish companies in 2018 were in the United Kingdom and Serbia 13\% (DEIK and Bain \& Company, 2019).

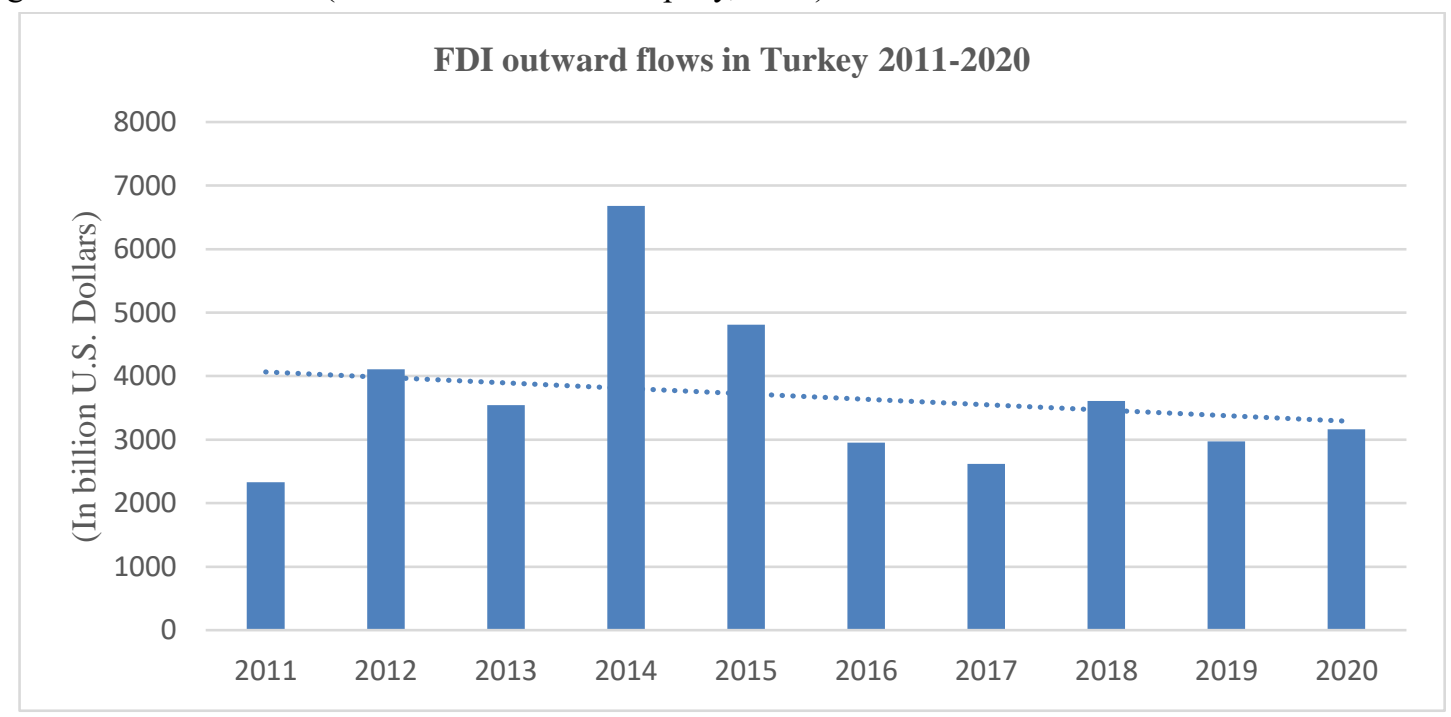

Figure 2. FDI Outward flows in Turkey 2011-2020 (billion US \$). Source: Statista (2021).

Foreign direct investment, net outflows (BoP, current US\$) - Turkey Foreign direct investment, net inflows (BoP, current US\$) - Turkey 


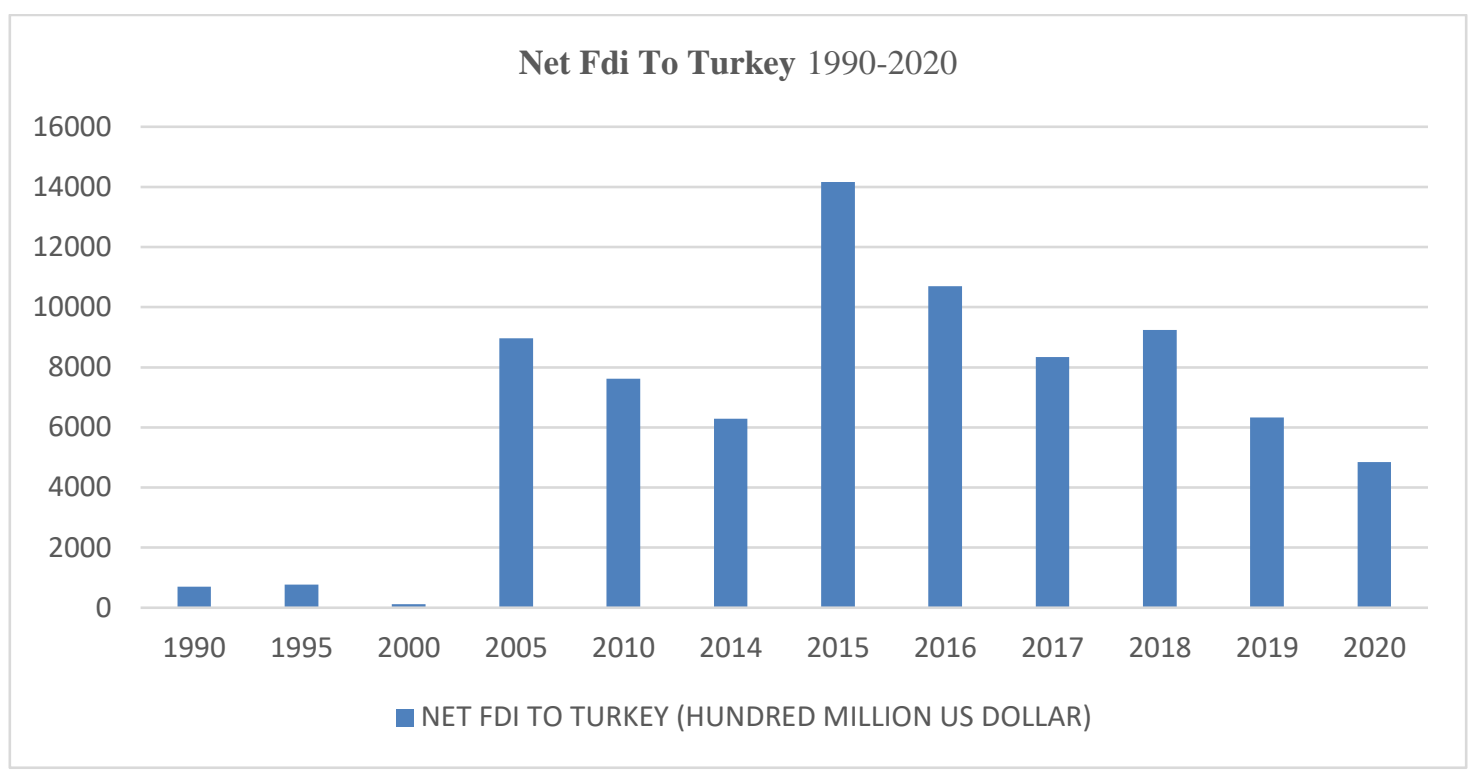

Figure 3. Net FDI inflows to Turkey 1990-2020 period Source: World Bank, 2021e

The TUIK's (Turkish Statistical Institute) surveys classify families as "poor" if their incomes are less than $60 \%$ of the median income. TUIK (2019) survey found that $21.5 \%$ of families in the country were poor According to the 2019 survey, which is the most recent one, up to 17 million people live below the poverty line in Turkey (AlMonitor, 2021).

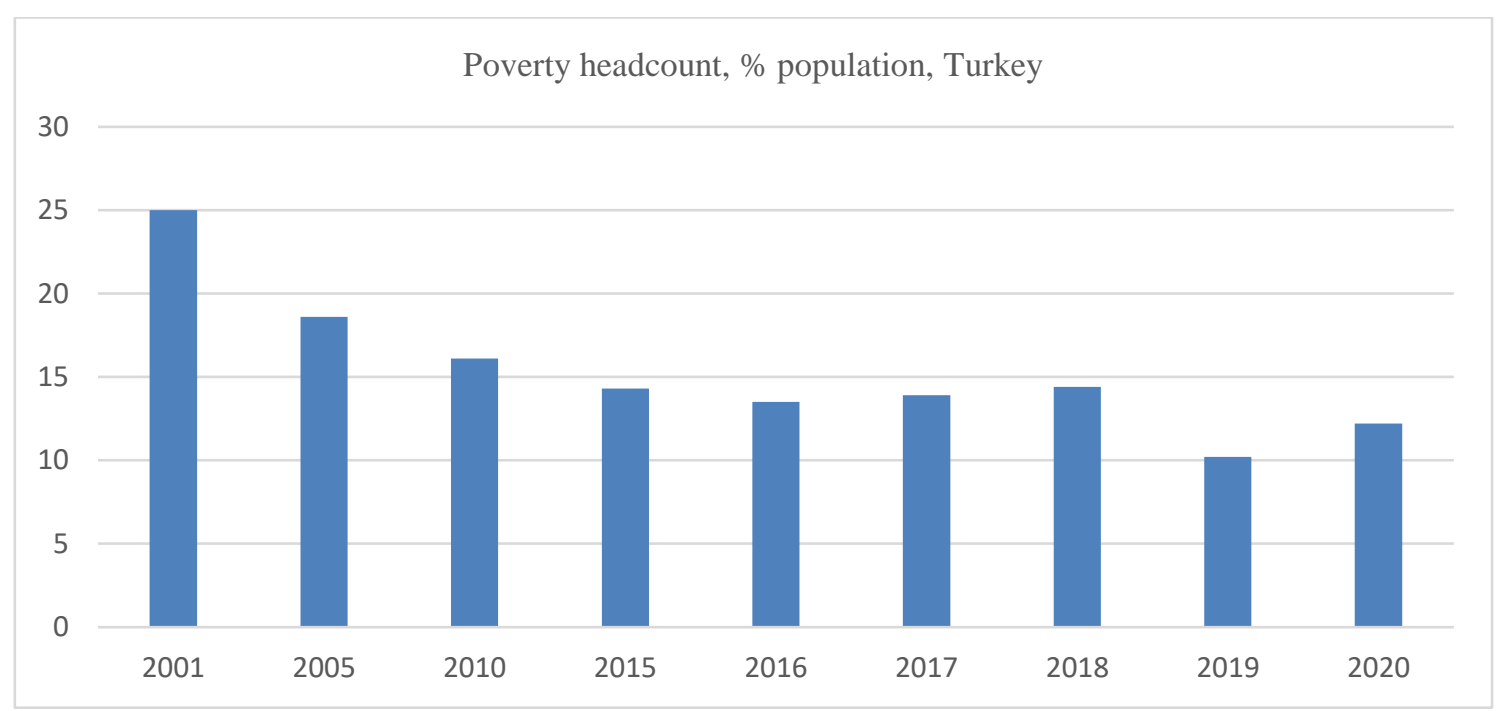

Figure 2. Poverty Headcount of Turkey 2001-2020 (\%). Source: WB (2021b).

\section{Methodology}

In this study, that aims to examine the effect of changes in foreign direct capital inflows on poverty reduction, the data set covers the period the 1996-2019. Time series data for Turkey between 1996-2019 period households and NPISHs final consumption expenditure (constant 2010 US\$), foreign direct investment, net inflows (BoP, current US\$) and GDP (constant 2010 US\$) were taken from World Bank Development Indicators (WB, 2021c). STATA 14 program used for econometric analysis. The logarithmic values of the series were used in the analysis.

In empirical studies using time series, it is recommended to use different proxies to measure poverty. In this context, recently it is seen that the reported consumption expenditure per capita, which has a very stable structure, is used as an indicator of poverty (Ravallion, 1992). Household spending is the sum of final consumption expenditure made by households to satisfy their daily. Researchers and policy makers are mostly interested in household consumption due to its conventional metric to evaluate poverty (Meyer and Sullivan, 2003).

According to Odhiambo (2009), per capita consumption expenditures are also consistent with the World Bank's definition of poverty as "not being able to provide a minimum standard of living". Although the expenditures of per capita consumption are not a quality indicator for measuring poverty, there is no harm in using it as a proxy 
variable (Şahbaz, et. al, 2016: 1111). A time series is stationary if its mean, variance, and covariance do not change over time. However, it is also possible for the time series to have a stochastic trend and its average to change over time. If such a situation is in question, it is stated that the spurious regression problem may arise in the analyzes to be made with these series (Granger and Newbold, 1974).

To investigate whether the effect of foreign direct investment on poverty reduction for Turkey the model is specifed as,

$$
\text { lnhousehold } t_{t}=\alpha_{0}+\beta_{1} \text { fdi }_{t}+\beta_{2} \text { gdp }_{t}+e_{t}
$$

where, household stands for (proxy variable for poverty) households and NPISHs final consumption expenditure, fdi represents foreign direct investment net inflows, gdp stands for GDP of Turkey and household is the dependent variable.

All series were found not stationary when the Augmented Dickey-Fuller (ADF) test for unit root test applied. The time-series properties of the variables used in the estimation process were examined with the Augmented Dickey-Fuller (ADF) unit root test developed by Dickey and Fuller (1979). While determining the optimal lag length for the VAR model, final prediction error (FPE), Akaike (AIC), Schwarz (SC) and Hannan-Quinn (HQ) information criteria were used and because all four criteria show a lag length of 1, the lag level was taken as 1 in the estimation.

\begin{tabular}{|l|l|l|l|l|l|l|l|l|}
\hline lag & LL & LR & df & $\mathrm{p}$ & FPE & AIC & HQIC & SBIC \\
\hline 0 & -1517.33 & & & & $2.1 \mathrm{e}+62$ & 152.033 & 152.063 & 152.183 \\
\hline 1 & -1454.62 & 125.43 & 9 & 0.000 & $1.0 \mathrm{e}+60^{*}$ & $146.662^{*}$ & $146.779^{*}$ & $147.26^{*}$ \\
\hline 2 & -1446.90 & 15.447 & 9 & 0.079 & $1.2 \mathrm{e}+60$ & 146.79 & 146.994 & 147.835 \\
\hline 3 & -1441.87 & 10.051 & 9 & 0.346 & $2.3 \mathrm{e}+60$ & 147.187 & 147.479 & 148.681 \\
\hline 4 & -1428.66 & $26.42^{*}$ & 9 & 0.002 & $2.3 \mathrm{e}+60$ & 146.766 & 147.145 & 148.708 \\
\hline
\end{tabular}

Table 5. Results of lag selection

\begin{tabular}{|l|l|l|l|}
\hline Variables & $\mathrm{Z}(\mathrm{t})$ & $\% 5$ & $\begin{array}{l}\text { MacKinnon p-value } \\
\text { for } \mathrm{Z}(\mathrm{t})\end{array}$ \\
\hline household lag(1) & 0,801 & $-3,000$ & 0,9916 \\
\hline fdi lag(1) & 0,247 & $-3,000$ & 0,2475 \\
\hline gdp lag(1) & 1,036 & $-3,000$ & 0,9946 \\
\hline
\end{tabular}

Table 6. Results of Augmented Dickey-Fuller (ADF) test

After taken first differences all time series became stationary.

\begin{tabular}{|l|l|l|l|}
\hline Variables & $\mathrm{Z}(\mathrm{t})$ & $\% 5$ & $\begin{array}{l}\text { MacKinnon p-value } \\
\text { for Z(t) }\end{array}$ \\
\hline household dif(1) & $-3,747$ & $-3,000$ & 0,0035 \\
\hline fdi dif(1) & $-3,793$ & $-3,000$ & 0,0030 \\
\hline gdp dif(1) & $-3,487$ & $-3,000$ & 0,0083 \\
\hline
\end{tabular}

Table 7. Results of MacKinnon approximate p-value for $Z(t)$

\begin{tabular}{|l|l|l|l|l|l|}
\hline $\begin{array}{l}\text { maximum } \\
\text { rank }\end{array}$ & parms & LL & eigenvalue & trace statistic & $\begin{array}{l}\% 5 \text { critical } \\
\text { value }\end{array}$ \\
\hline 0 & 12 & -1541.8798 &. & 30.8100 & 29.68 \\
\hline 1 & 17 & -1533.3873 & 0.55461 & $13.8250^{*}$ & 15.41 \\
\hline 2 & 20 & -1527.6032 & 0.42355 & 2.2567 & 3.76 \\
\hline 3 & 21 & -1526.4748 & 0.10189 & & \\
\hline
\end{tabular}

Table 8. Results of VECM model

All variables were tested for long-term cointegration relationship by using Johansen cointegration test so for long-term relationships, Johansen (1988) test for cointegration applied. After Johansen normalization restriction imposed, results are:

\begin{tabular}{|l|l|l|l|l|ll|}
\hline beta & Coef. & Std. Err. & $\mathrm{Z}$ & $\mathrm{P}>|\mathrm{z}|$ & {$[95 \%$ Conf. Interval] } \\
\hline $\begin{array}{l}\text { ce1 } \\
\text { householdvar }\end{array}$ & 1 &. &. &. & & \\
\hline fdivar & 0.011 & 0.006 & 1.87 & 0.062 & -.0005639 & .022914 \\
\hline gdpvar & -0.931 & 0.023 & -39.74 & 0.000 & -.9765734 & -.8847694 \\
\hline cons & -1.643 &. &. &. &. & \\
\hline
\end{tabular}

Table 9. Johansen normalization 
The parameter estimates of the normalized equation obtained from the cointegration relationship between the variables are presented in Table 10.

\begin{tabular}{|c|}
\hline Normalized Cointegration Equation \\
\hline household (final consumption) $=0.011 \mathrm{fdi}-0.931 \mathrm{gdp}$ \\
\hline
\end{tabular}

Table 10. Estimation of Cointegration Equation

According to these coefficients, which also show their long-term elasticity, they reveal that the elasticity of per capita consumption is positive in terms of FDI inflows. A 1\% increase in foreign direct capital inflows increases household final consumption (proxy variable used for poverty) by about $0.011 \%$. Likewise, a $1 \%$ increase in GDP decreases household final consumption by (proxy variable used for poverty) approximately $0.931 \%$.

Granger causality Wald tests confirm no casual relationship between fdi and gdp variables.

\begin{tabular}{|l|l|l|l|l|}
\hline Equation & Excluded & chi2 & df & Prob > chi2 \\
\hline householdvar & fdivar & 1.124 & 1 & 0.289 \\
\hline householdvar & gdpvar & .853 & 1 & 0.355 \\
\hline householdvar & ALL & 2.96 & 2 & 0.228 \\
\hline fdivar & householdvar & .150 & 1 & 0.698 \\
\hline fdivar & gdpvar & .005 & 1 & 0.944 \\
\hline fdivar & ALL & 1.29 & 2 & 0.523 \\
\hline gdpvar & householdvar & 1.80 & 1 & 0.179 \\
\hline gdpvar & fdivar & 1.18 & 1 & 0.276 \\
\hline gdpvar & ALL & 3.62 & 2 & 0.163 \\
\hline
\end{tabular}

Table 11. Granger causality results

\section{Conclusion}

FDI has promoted effective economic growth in several developing countries as a stimulus in economic growth. For several decades FDI and economic growth have a relationship which has been a topical issue. FDI's net employment effect should take in consideration as well.

To attract more FDI, Turkey needs to develop enforcement of international trade rules, secure the transparency and convenient implementation of legal systems, increase commitment with foreign investors on policy matters, and follow policies to encourage sustainable, and balanced economic growth. Turkey also needs to take other political measures to strengthen secureness and predictability for foreign investors.

A time-series analysis of foreign direct investments and poverty reduction for Turkey between the 1996-2019 period confirms as expected economic literature foreign direct investments reduce poverty. Turkish policymakers should develop an appropriate economic environment to appeal as much as foreign direct investment to Turkey. Econometric analysis reveals that a \%1 increase of FDI inflow to Turkey increases \% 0.11 of Household final consumption which is used as a proxy variable representing poverty. Thus, Turkish policymakers should develop an appropriate economic environment for competing (export processing zones and tax incentives) to appeal as much as foreign direct investment to Turkey among other developing countries. Policies for improving the human capital of workers (STEM education) can attract more FDI inflows due to technical developments in lean production processes happening in Industrial Revolution 4.0 and the digital transformation of society 5.0.

\section{References}

- Ahmad, Draz, Su, Ozturk, Rauf and Ali, 2019. "Impact of FDI Inflows on Poverty Reduction in the

- ASEAN and SAARC Economies". Sustainability 2019, 11, 2565; doi:10.3390/su11092565.

- www.mdpi.com/journal/sustainability

- Ali, Nishat. and Anwar, 2010. "Do foreign inflows benefit Pakistan poor?" The Pakistan Development Review, no. 48 (4).

- Al-Monitor, 2021. Mustafa Sönmez, 27.01.2021. COVID-19 pandemic expands poverty in Turkey. https://www.al-monitor.com/originals/2021/01/turkey-pandemic-pandemic-expands-poverty-highinflation.html

- Ato-Mensah, and Long, 2021.” Impact of FDI on Economic Growth, Employment, and Poverty Reduction in Ghana". Open Journal of Business and Management, 9, 1291-1296. https://doi.org/10.4236/ojbm.2021.93069

- $\quad$ Apergis, Lyroudia and Vamvakidis, 2007. "The Relationship Between Foreign Direct Economic Growth: Evidence from Transitional Countries”, Working Paper SSRN No. 990251. 
- Arabyat, 2017. "The impact of foreign direct investment on poverty reduction in the developing countries". International Finance and Banking, 4 (2), pp. 92-111.

- Awunyo-Vitor, and Sackey, 2018. “Agricultural Sector Foreign Direct Investment and Economic Growth in Ghana”. Journal of Innovation and Entrepreneurship, 7, Article Number: 15. https://doi.org/10.1186/s13731-018-0094-3

- Basnet, and Pradhan, (2014). "Does the Inflow of FDI Stock Matter? Evidence from SAARC Countries". Econ. Pap., 33, 305-312.

- Busse Groizard, 2005. "FDI, Regulations and Growth" [online] http://www.webs.uvigo.es/viijpe/pdf/BUSSEGRIZAED.PDF.

- DEIK and Bain \& Company, 2019. Outbound Investment Index 2019. https://www.deik.org.tr/bilgimerkezi-yayinlar

- Dickey, and Fuller, 1979. "Distribution of the Estimators for Autoregressive Time Series With a Unit Root". Journal of the American Statistical Association, 74(366), 427-431. doi:10.2307/2286348

- Durowah, 2017. The role of aid for trade and foreign direct investment in poverty reduction: A panel data analysis of 91 developing countries. Theses and Dissertations.1187. http://openprairie.sdstate.edu/etd/1187

- Fauzel, Seetanah and Sannassee, 2016. "A Dynamic Investigation of Foreign Direct Investment and Poverty Reduction in Mauritius”. Theoretical Economics Letters, 6, 289-303. doi: 10.4236/tel.2016.62033.

- Fowowe and Shuaibu, 2014. "Is foreign direct investment good for the poor? New evidence from African countries”. Econ Change Restruct 47, 321-339. https://doi.org/10.1007/s10644-014-9152-4.

- Granger, and Newbold, 1974. "Spurious regressions in econometrics". Journal of Econometrics, 2 (2), ss. 111-120.

- Gohou and Soumare, 2012. "Does foreign direct investment reduce poverty in Africa and are there regional differences?” World Development, 40 (1), pp. 75-95.

- Hale, Xu, 2016. "FDI effects on the labor market of host countries" Federal Reserve Bank of San Francisco Working Paper 2016-25. http://www.frbsf.org/economicresearch/publications/working-papers/wp201625.pdf

- Hanim, 2021. "How Does Foreign Direct Investment (FDI) Reduce Poverty? Application of the Triangular Hypothesis for the Indonesian Case". Review of Integrative Business and Economics Research, Vol. 10, Supplementary Issue 1

- Hansen and Rand, 2006. "On the Causal Links Between FDI and Growth in Developing Countries", The Word Economy, 29, 1, 21-41.

- Herzer, Klasen, Nowak-Lehmann, (2008). "In Search of FDI-led Growth in Developing Countries: The way Forward". Econ. Model., 25, 793-810.

- Herzer, 2012. “How Does Foreign Direct Investment Really Affect Developing Countries' Growth?” Rev. Int. Econ., 20, 396-414.

- Hmani, 2017. "Interaction between FDI, poverty and inequality: Analysis in simultaneous equations". International Journal of Advances in Management and Economics, 6 (4), pp. 35-48.

- Huang, Teng and Tsai, 2010. "Inward and outward foreign direct investment and poverty reduction: East Asia versus Latin America”, Review of World Economics, no. 146 (4).

- Hürriyet, 2017. Turkish businesses FDI outflow rises 10 times in 15 years: Index. https://www.hurriyetdailynews.com/turkish-businesses-fdi-outflow-rises-10-times-in-15-years-index-113222

- Investment Office, 2021. https:/www.invest.gov.tr/en/whyturkey/pages/fdi-in-turkey.aspx

- Jalilian and Weiss, 2002. "Foreign direct investment and poverty in the ASEAN region". ASEAN Economic Bulletin, 19 (3), pp. 231-253.

- Johansen, 1988. "Statistical analysis of cointegration vectors", Journal of Economic Dynamics and Control, Volume 12, Issues 2-3, Pages 231-254, ISSN 0165-1889, https://doi.org/10.1016/0165-1889(88)90041-3.

- Lazreg and Zouari, 2018. "The impact of FDI on poverty reduction in North Africa". Journal of Economics and Management Sciences, 1 (1), pp. 37-50.

- Le, Do, Pham, and Nguyen. 2021. “The Impact of Foreign Direct Investment on Income Inequality in Vietnam". Economies 9: 27. https://doi.org/10.3390/ economies9010027

- Magombeyi, Tsitsi; Odhiambo, 2017. "Foreign direct investment and poverty reduction", Comparative Economic Research, De Gruyter, Warsaw, Vol. 20, Iss. 2, pp. 73-89. http://dx.doi.org/10.1515/cer-2017-0013 
- Meyer, and Sullivan, 2003. "Measuring the Well-Being of the Poor Using Income and Consumption". Journal of Human Resources, 1180-1220.

- $\quad$ Nur and Dilber, 2017. "Gelişmekte Olan Ülkelerde Doğrudan Yabancı Yatırımları Belirleyen Temel Unsurlar”. Dokuz Eylül Üniversitesi İktisadi ve İdari Bilimler Fakültesi Dergisi. Cilt:32, Sayı:2, Y11:2017, ss. $15-45$.

- Nourbakhshian, Hosseini, Aghapour and Gheshmi, 2012. "The Contribution of Foreign Direct Investment into Home Country's Development”. International Journal of Business and Social Science Vol. 3 No. 2 [Special Issue - January 2012]

- Ogunniyi and Igberi, 2014. "The impact of foreign direct investment on poverty reduction in Nigeria", Journal of Economics and Sustainable Development, no. 5(14).

- Ravallion, 1992. "Poverty comparisons: a guide to concepts and methods, living standards measurement study", Working Paper 88. World Bank, Washington, DC.

- $\quad$ Reiter and Steensma, 2010. "Human development and foreign direct investment in developing countries: the influence of foreign direct investment policy and corruption", World Development, no. 38 (12).

- Sikandar, Erokhin, Wang, Rehman, and Ivolga, 2021. "The Impact of Foreign Capital Inflows on Agriculture Development and Poverty Reduction: Panel Data Analysis for Developing Countries”. Sustainability 2021, 13, 3242. https:// doi.org/10.3390/su13063242

- $\quad$ Statista, 2021. Value of foreign direct investment (FDI) outward flows in Turkey from 2011 to 2020. https:/www.statista.com/statistics/933282/value-of-foreign-direct-investment-outward-flows-in-turkey/

- Soumare, 2015. Does Foreign Direct Investment Improve Welfare in North Africa? Africa Development Bank.

- Şahbaz, Buluş, and Kaleci, 2016. "The Relationship between Openness, Foreign Direct Investment, and Poverty: The Case of Turkey”. Gaziantep University Journal of Social Sciences, 15 (4), 1106-1117. DOI: $10.21547 /$ jss. 265500

- TUIK, 2019. HaberBultenleri. https://tuikweb.tuik.gov.tr/PreHaberBultenleri.do?id=33820

- Trinh, 2017. Poverty reduction in Vietnam: "The role of foreign direct investment". International Journal of Management and Applied Science, 3 (2), pp. 84-89.

- Tsaruai, 2018. "Investigating The Impact of Foreign Direct Investment on Poverty Reduction Efforts in Africa”. Revista Galega de Economia. Vol.27-2.

- Uttama, 2015. Foreign direct investment and the poverty reduction nexus in Southeast Asia. In: Heshmati A. Maasoumi E. Wan G. (eds) Poverty Reduction Policies and Practices in Developing Asia. Economic Studies in Inequality, Social Exclusion and Well-Being. Springer, Singapore.

- Zaman, Khan and Ahmad, 2012. "The relationship between foreign direct investment and pro-poor growth policies in Pakistan”. The new interface, Economic Modelling no. 29.

- UNCTAD, 2012. World Investment Report 2012. https://unctad.org/webflyer/world-investment-report-2012

- UNCTAD, 2021. Investment Trends Monitor 2021, https://unctad.org.

- WorldBank, 2021a. FDI inflows of Turkey, https://data.worldbank.org/indicator/BX.KLT.DINV.CD.WD.

- World Bank, 2021b. Poverty headcount of Turkey. https://data.worldbank.org/indicator/SI.POV.NAHC.

- World Bank, 2021c. World Development Indicators. Turkey. https://databank.worldbank.org/source/worlddevelopment-indicators

- World Bank, 2021d. Ease of Doing Business rankings. https://www.doingbusiness.org/en/rankings

- World Bank, 2021e. Foreign direct investment, net inflows (BoP, current US\$) - Turkey. https://data.worldbank.org/indicator/BX.KLT.DINV.CD.WD?locations=TR 